\title{
Relating changes in agricultural practices to increasing dew points in extreme Chicago heat waves
}

\author{
David Changnon*, Michael Sandstrom, Charles Schaffer
}

Meteorology Program, Department of Geography, Northern Illinois University, DeKalb, Illinois 60115, USA

\begin{abstract}
The temporal distribution of surface atmospheric water vapor levels during shortduration extreme heat events at Chicago was assessed. Heat events were characterized by at least 3 consecutive days with a minimum temperature greater than $24^{\circ} \mathrm{C}\left(75^{\circ} \mathrm{F}\right)$ and a maximum temperature greater than $35^{\circ} \mathrm{C}\left(95^{\circ} \mathrm{F}\right)$. Thirteen such heat events were identified during the 75 yr (1928-2002) record at Chicago Midway Airport located inside the city. Average dew points in events fluctuated considerably over time, but generally increased. Event average hourly dew-point values before the mid 1980s were generally below $21^{\circ} \mathrm{C}$, rising to an average of $24^{\circ} \mathrm{C}$ during the mid $1990 \mathrm{~s}$. The temporal changes in dew-point values were related to 2 factors: (1) the existence of average to aboveaverage regional precipitation anomalies occurring in May and during the $20 \mathrm{~d}$ period prior to the heat event, and (2) changes in agricultural practices that have led to enhanced evapotranspiration rates in the Midwest.
\end{abstract}

KEY WORDS: Short-duration heat waves · Surface dew-point temperature · Chicago · Climate variability $\cdot$ Evapotranspiration

\section{INTRODUCTION}

Wide variations in daily weather conditions occur throughout the year in Chicago, including heavy rains or snows, large changes in air temperature, and extremes that can range from winter lows near $-30^{\circ} \mathrm{C}$ $\left(-22^{\circ} \mathrm{F}\right)$ to summer highs near $40^{\circ} \mathrm{C}\left(104^{\circ} \mathrm{F}\right)$. When unusually hot or cold extremes persist for several days, significant economic and social losses result. Specifically, heat waves affect several weather-sensitive industries, such as energy and agriculture, as well as human health and comfort (Kalkstein \& Davis 1989, Changnon 2002). Energy usage largely reflects daily weather conditions, and extreme events define the maximum energy demand placed upon utilities (Changnon et al. 1996, Cohen \& Kosar 2000). Most importantly, heat-induced stress on the human body can lead to fatalities, especially when enhanced by high water vapor levels. Heat waves are a major cause of weather-related deaths (Robinson 2000a). In mid-
July 1995, a brief but intense Midwestern heat episode resulted in over 1000 deaths (Kunkel et al. 1996).

Previous studies of Midwestern short-duration heat events have focused on specific events. A study of the 1995 heat wave in Chicago (Kunkel et al. 1996) found that the high number of fatalities was partially the result of much higher than normal daily minimum temperatures, making it more difficult for the body to cool. They also concluded that this event was synoptically unusual because of a significant urban heat island effect and extremely high dew point temperatures. Using climate data from a number of locations in or near Chicago, they found that the intensity of this short duration heat wave (based on average air temperature) was surpassed by 2 previous events, both occurring in the 'dust bowl' years of the mid 1930s.

A study of the 1999 Midwestern heat wave by Palecki et al. (2001) found this event to be similar to the 1995 event at Chicago in intensity (in terms of air and dew point temperatures), but of shorter duration. Mid- 
western heat-related fatalities were nearly one-fourth of those in 1995, a reduction partially due to improved municipal response efforts for heat waves.

Record high dew points experienced during these 2 events of the 1990s raised questions about dew point levels experienced during earlier Chicago heat waves. A recent study (Sparks et al. 2002) identified that the frequency of hours with extreme dew points $\left(>24^{\circ} \mathrm{C}\right)$ at 2 northeastern Illinois first-order NWS stations, Rockford and Chicago O'Hare, had increased significantly during a 42 yr period (1959-2000).

The primary goal of this study was to determine whether and why dew point levels had changed over time during short-duration Chicago heat waves. The Chicago Midway Airport weather records were examined for a $75 \mathrm{yr}$ period (1928-2002). Any changes would have a significant impact on human health, the design and operation of air conditioning systems, as well as electrical demand in the Midwest (Cohen \& Kosar 2000, Changnon 2002, Sparks et al. 2002).

Both Kunkel et al. (1996) and Palecki et al. (2001) concluded that the extreme high dew points experienced during the 1995 and 1999 heat events occurred as a result of widespread regional rainfalls that preceded the heat waves. These rains were believed to have increased evapotranspiration rates from actively growing Midwestern corn (Zea mays L.) and soybean (Glycine max L.) crops. Studies that examined conditions prior to the development of Midwest mesoscale convective systems (MCSs) postulated that the primary source for low-level moisture during weak-flow (anticyclonic) situations was evapotranspiration from crops, not moisture advection from the Gulf of Mexico (Chang \& Wetzel 1991, Bentley \& Mote 1998, Changnon \& Kunkel 1999). The possibility exists that changes in agricultural practices relating to corn and soybean production have also had an influence on the amount of evapotranspiration from an acre of Midwestern farm land. Pielke et al. (2002) suggested that the influence of land-cover/land-use changes on regional and global climate variability and change may be underestimated and suggested that further research in this area was needed. Thus, a secondary goal of this research was to explore these factors (rainfall anomalies during the growing season prior to the high heat event, and changes in agricultural practices over time) to determine whether they might be linked to the dew point levels experienced during short-duration Chicago heat waves.

\section{DATA AND METHODOLOGY}

An important aspect of this research was to develop a meaningful definition of a short-duration heat wave for Chicago. Although there may be an infinite number of temperature-related definitions (Robinson 2000a), this project sought to identify extreme events that created numerous local impacts. In a study that examined extreme summer temperatures in the southeast US, Changnon (1993) selected a common threshold, daily maximum temperatures ( $T_{\max }$ ) equal to or greater than $32^{\circ} \mathrm{C}\left(90^{\circ} \mathrm{F}\right)$, based on its perceived impact on regional utility operations. The 2 most recent severe Chicago heat events, those in July of 1995 and 1999, helped to determine the short-duration heat-wave characteristics used in this study. Kunkel et al. (1996) chose $4 \mathrm{~d}$ periods, based on the length of the intense heat experienced in Chicago during the 1995 event to rank Chicago heat waves.

Because impacts on utilities and human health generally peak after the first day of a heat event (Kalkstein \& Davis 1989, Changnon 1993), a heat wave in this study was defined as meeting temperature thresholds for 3 or more consecutive days. This study differs from previous studies by using both a $T_{\max }$ and $T_{\min }$ threshold. The decision to use a $T_{\min }$ threshold was based on the research by Kunkel et al. (1996) and Palecki et al. (2001), which identified that high minimum temperatures experienced in the 1995 and 1999 events created severe health-related impacts.

The Chicago Midway Airport National Weather Service (NWS) station has the longest continuous record of temperature and dew-point observations for Chicago (1928-present) and was used in this study. A $T_{\max }$ of $35^{\circ} \mathrm{C}\left(95^{\circ} \mathrm{F}\right)$ and a $T_{\min }$ of $24^{\circ} \mathrm{C}\left(75^{\circ} \mathrm{F}\right)$ were selected as threshold temperatures as they occurred on less than $1 \%$ of all summer days at Chicago Midway, and each day meeting this criteria was found to have created severe regional impacts. Thirteen events met these criteria. By comparison, if the $T_{\max }$ and $T_{\min }$ thresholds were shifted $1{ }^{\circ} \mathrm{C}$ higher $\left(36^{\circ} \mathrm{C}\right.$ and $25^{\circ} \mathrm{C}$ respectively) there would be only 2 events, and if the thresholds were both reduced $1^{\circ} \mathrm{C}\left(34^{\circ} \mathrm{C}\right.$ and $23^{\circ} \mathrm{C}$ respectively) the number of events would have increased to 31 . Thus, the thirteen $3 \mathrm{~d}$ or longer periods meeting both temperature conditions $\left(T_{\max }\right.$ of $35^{\circ} \mathrm{C}$ and $T_{\min }$ of $24^{\circ} \mathrm{C}$ ) were considered to be an adequate sample of very extreme short-duration heat events during this $75 \mathrm{yr}$ period. These events were expected to be characterized by relatively high dew points because daily minimum temperatures are generally similar to dew-point temperatures.

The official Chicago Midway historical daily $T_{\max }$ and $T_{\min }$ record for the period 1928-1980 was observed at the airport location, whereas official values after January 16, 1980, were based on observations taken at a NWS cooperative station located 3 miles $(5 \mathrm{~km})$ southwest of the airport (National Climatic Data Center [NCDC] TD-3200 and pre-1948 data digitized by 
the Midwestern Regional Climate Center; Kunkel et al. 1998).

Statistical tests were conducted to compare the $T_{\max }$ and $T_{\min }$ values taken at the cooperative station with those based on the hourly measurements taken at the airport which continued after 1980. Monthly average differences between the 2 nearby locations were generally less than $1^{\circ} \mathrm{C}$, and Student $t$-tests indicated that these differences were not significant at the $5 \%$ level. No significant difference was found when comparing $T_{\max }$ and $T_{\min }$ values from the 2 locations during shortduration heat events which occurred after 1980. Thus, for this analysis, these 2 urban locations were viewed as having a similar $T_{\max }$ and $T_{\min }$ climatology.

Hourly air and dew-point temperature data were obtained for each day of each qualifying event. The hourly data were solely from Chicago Midway during the 75 yr period (NCDC TD-3280 and paper records obtained from Midway observer, Mr Frank Wachowski). An event average hourly temperature was computed by adding each hourly temperature, then dividing by the number of hours in the event. Because $T_{\max }$ and $T_{\min }$ were determined for a $24 \mathrm{~h}$ period which begins and ends at midnight, all $24 \mathrm{~h}$ observations in a day that met both the $T_{\max }$ and $T_{\min }$ thresholds were used to determine an event average. For example, the July 12-15, 1995 event average temperature and dew point were based on using all $96 \mathrm{~h}$ of data in those $4 \mathrm{~d}$.

A concern is the quality of the historical dew-point data. Dew-point measurement techniques at firstorder NWS stations such as Chicago Midway have changed over time. Elliott (1995), Gaffen \& Ross (1999), Robinson (2000b), and Sparks et al. (2002) documented that through the early 1960s sling psychrometers were primarily used. Then, from the early 1960s through the mid 1980s lithium chloride hygrothermometers were used, and from the mid 1980s through the mid 1990s the hygrothermometer model HO-83 was used. Since the mid 1990s the NWS has implemented the Automated Surface Observing System (ASOS), which records dew-point temperature with a modified version of the HO-83. The dew point sensor has a chilled mirror that condenses moisture on the surface. When the sensor detects condensation, the instrument determines what temperature (the dew-point temperature) is needed to keep the sensor at equilibrium with the surrounding air (Schafer \& Stark 1997). Research by Gaffen \& Ross (1999) and Robinson (2000b) indicated that no detectable dew-point changes (no systematic biases) were associated with these equipment and instrumentation changes at NWS first-order stations. Based on these findings, the observed hourly dewpoint values associated with the short-duration heat events were used.
The number of hours with dew points equal to or greater than 4 arbitrarily selected thresholds (18 [65], 21 [70], 24 [75], and $\left.27^{\circ} \mathrm{C}\left[80^{\circ} \mathrm{F}\right]\right)$ were computed for each short-duration heat event to help determine dewpoint intensity. All events were not of the same duration, so a 'number of hours per day' value was developed for each dew-point threshold for each event. This average value was computed by dividing the total number of hours equal to or greater than a particular threshold by the number of days in the event.

\section{RESULTS}

A total of thirteen $3 \mathrm{~d}$ or longer short-duration heat events (those that met both the $T_{\max }$ and $T_{\min }$ temperature criteria) dating back to 1928 were found in the Chicago Midway record. Of these, 10 events were $3 \mathrm{~d}$ in length and 3 were $4 \mathrm{~d}$ long (Table 1). There were 2 events in one year (1995), but the others were from different years. Heat events were ranked based on the average hourly air temperature during each event (Table 1). Because the levels for the $T_{\max }$ and $T_{\min }$ thresholds were extreme, the average hourly temperature values for all events were expected to be generally similar, and this was the case as values ranged from 29.2 to $32.9^{\circ} \mathrm{C}$. Of the top 4 short-duration heat waves, 3 were the most recent: July 1995, August 1995, and July 1999. However, after the fourth highest event, the ranking of the other 9 events did not indicate any organized temporal distribution.

The event average hourly dew points were also assessed (Table 2). The most severe event was in July of 1995 , with an average hourly dew point of $24.6^{\circ} \mathrm{C}$. The lowest average dew point was $15.9^{\circ} \mathrm{C}$, during the 1953 event. The range in average dew-point values

Table 1. Ranked event average hourly air temperatures for 13 Chicago Midway short-duration heat events

\begin{tabular}{|lccc|}
\hline Month & Days & Year & $\begin{array}{c}\text { Average hourly } \\
\text { temperature }\left({ }^{\circ} \mathrm{C}\right)\end{array}$ \\
\hline Jul & $12-15$ & 1995 & 32.9 \\
Jul & $10-12$ & 1936 & 32.3 \\
Jul & $28-30$ & 1999 & 31.6 \\
Aug & $11-14$ & 1995 & 30.9 \\
Sep & $1-3$ & 1953 & 30.4 \\
Aug & $1-4$ & 1988 & 30.2 \\
Jul & $15-17$ & 1931 & 30.0 \\
Jun-Jul & $30-2$ & 1970 & 29.9 \\
Aug & $2-4$ & 1955 & 29.7 \\
Jun & $28-30$ & 1971 & 29.6 \\
Jul & $17-19$ & 1986 & 29.6 \\
Aug & $18-20$ & 1947 & 29.3 \\
Aug & $1-3$ & 1987 & 29.2 \\
\hline
\end{tabular}


Table 2. Ranked event average hourly dew point temperatures for 13 Chicago Midway short-duration heat events

\begin{tabular}{|lccc|}
\hline Month & Days & Year & $\begin{array}{c}\text { Average hourly } \\
\text { dew point }\left({ }^{\circ} \mathrm{C}\right)\end{array}$ \\
\hline Jul & $12-15$ & 1995 & 24.6 \\
Jul & $28-30$ & 1999 & 24.5 \\
Aug & $11-14$ & 1995 & 24.1 \\
Aug & $1-3$ & 1987 & 23.1 \\
Jul & $17-19$ & 1986 & 22.5 \\
Aug & $18-20$ & 1947 & 22.1 \\
Jun-Jul & $30-2$ & 1970 & 21.8 \\
Aug & $1-4$ & 1988 & 21.3 \\
Jul & $15-17$ & 1931 & 20.7 \\
Aug & $2-4$ & 1955 & 20.1 \\
Jun & $28-30$ & 1971 & 19.5 \\
Jul & $10-12$ & 1936 & 17.6 \\
Sep & $1-3$ & 1953 & 15.9 \\
& & & \\
\hline
\end{tabular}

was $8.7^{\circ} \mathrm{C}$, more than twice the range of the average air temperatures during these 13 events.

Importantly, not all heat events experienced similar dew-point values. For example, the August 1995 event ranked fourth in average air temperature $\left(30.9^{\circ} \mathrm{C}\right)$ and the 1953 event ranked fifth at $30.4^{\circ} \mathrm{C}$ (Table 1); however, the average dew-point temperature in the 1995 event was $24.1^{\circ} \mathrm{C}$, and in the event in 1953 it was $15.9^{\circ} \mathrm{C}$ (Table 2). The difference in air temperature between the events was only $0.5^{\circ} \mathrm{C}$, while the difference in dew-point temperatures was $8.2^{\circ} \mathrm{C}$. This indicated that atmospheric moisture levels associated with short-duration heat events are not just related to air temperatures, but must be influenced by other factors.

Although it is difficult to evaluate trends in random infrequent climate events, their temporal distribution revealed that the most recent short-duration heat

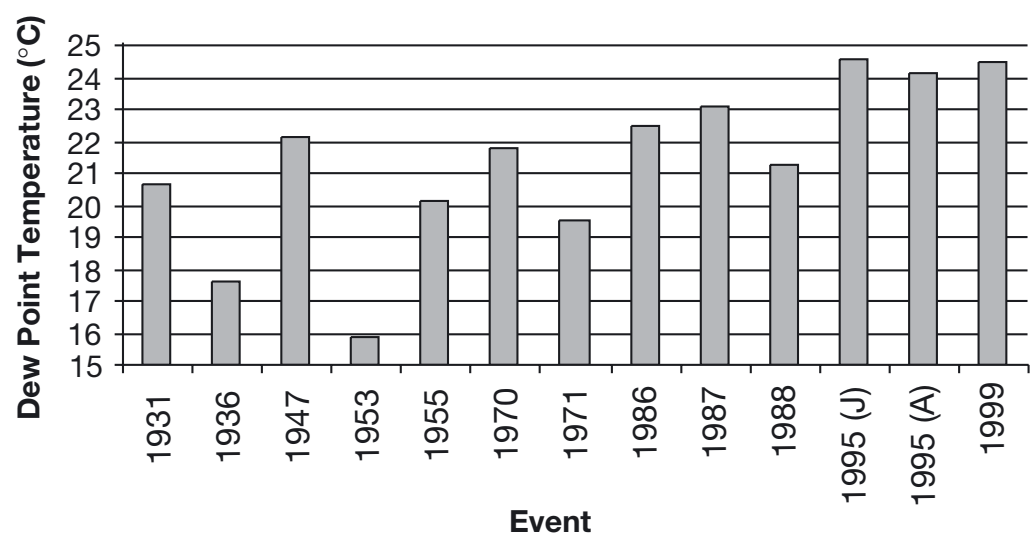

Fig. 1. Average hourly dew point for 13 Chicago Midway short-duration heat events (in chronological order). Events occured randomly during 1928-2002. For 1995 events, $\mathrm{J}=$ Jul and A = Aug events had experienced higher average dew-point levels than those before (Fig. 1). Five of the 6 short-duration heat events with an average dew point $\geq 22^{\circ} \mathrm{C}$ have occurred since the mid 1980s (Table 2). Interestingly, the 1988 heat event, which occurred in one of the driest summers in the Midwest during the twentieth century (Riebsame et al. 1991), experienced an average hourly dew point in the lower half of the event distribution. Furthermore, the 1936 heat event, which had the second highest air temperature on record, experienced the second lowest average hourly dew point.

The intensity of atmospheric water vapor levels with the individual short-duration heat waves was assessed using the average number of hours per day with dew points equal to or greater than 4 thresholds (Fig. 2). At the threshold value of $21^{\circ} \mathrm{C}\left(70^{\circ} \mathrm{F}\right)$, only 2 events failed to accumulate any hours: 1936 and 1953. At the threshold value of $24^{\circ} \mathrm{C}\left(75^{\circ} \mathrm{F}\right)$, no event prior to $1986 \mathrm{accu}-$ mulated any hours at or above this value. With the exception of the 1988 event, each event beginning with the 1986 event experienced an average of 2 or more $\mathrm{h} \mathrm{d}^{-1}$ with dew points equal to or greater than $24^{\circ} \mathrm{C}$. The 3 most recent events (July 1995, August 1995, and July 1999) each averaged more than $14 \mathrm{~h} \mathrm{~d}^{-1}$ (during the event) with dew points equal to or greater than $24^{\circ} \mathrm{C}$. The most extreme dew-point threshold value of $27^{\circ} \mathrm{C}\left(80^{\circ} \mathrm{F}\right)$, which is infrequently reached in the United States (US Department of Commerce 1968), was equaled or surpassed in July 1995 for a total of $29 \mathrm{~h}$ and in July 1999 for $18 \mathrm{~h}$. The results confirm that these 2 recent heat waves were anomalous when considering a number of factors related to temperature and dew point.

In summary, these various findings reveal that atmospheric water vapor levels associated with shortduration Chicago heat events have varied over time. Although fitting a statistical trend to the average dew-point values associated with the 13 randomly occurring events in $75 \mathrm{yr}$ would be a questionable act, the data shown in Figs 1 \& 2 suggest more recent values are higher. Previous research (Sparks et al. 2002) has indicated that the frequency of warm-season hourly extreme dew points (values $\geq 24^{\circ} \mathrm{C}$ ) has increased over a $42 \mathrm{yr}$ period (1959-2000) in northeastern Illinois. Based on those results, and because most recent (since 1980) shortduration Chicago heat events have higher average dew-point characteristics than earlier events, we sought to assess factors that could be enhancing water vapor levels at the surface. 


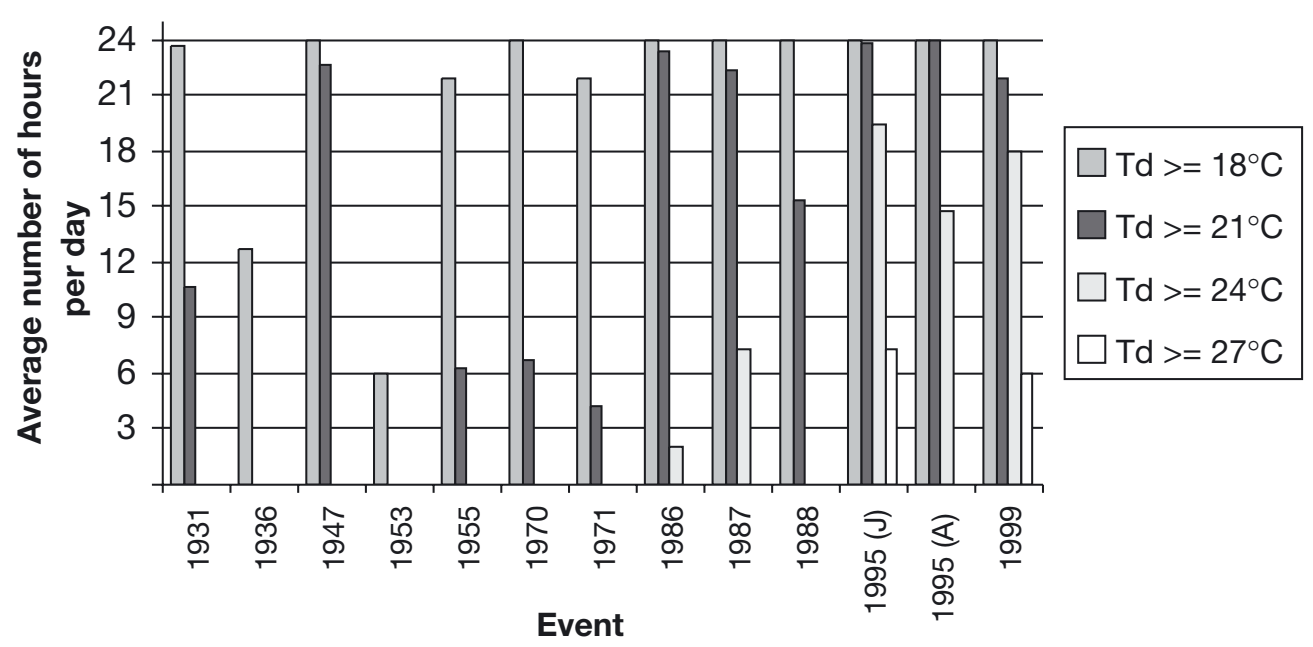

Fig. 2. Average number of hours per day with dew points equal to or greater than 4 thresholds (Td) for 13 Chicago Midway shortduration heat events (in chronological order). For 1995 events, $\mathrm{J}=\mathrm{Jul}$ and A = Aug

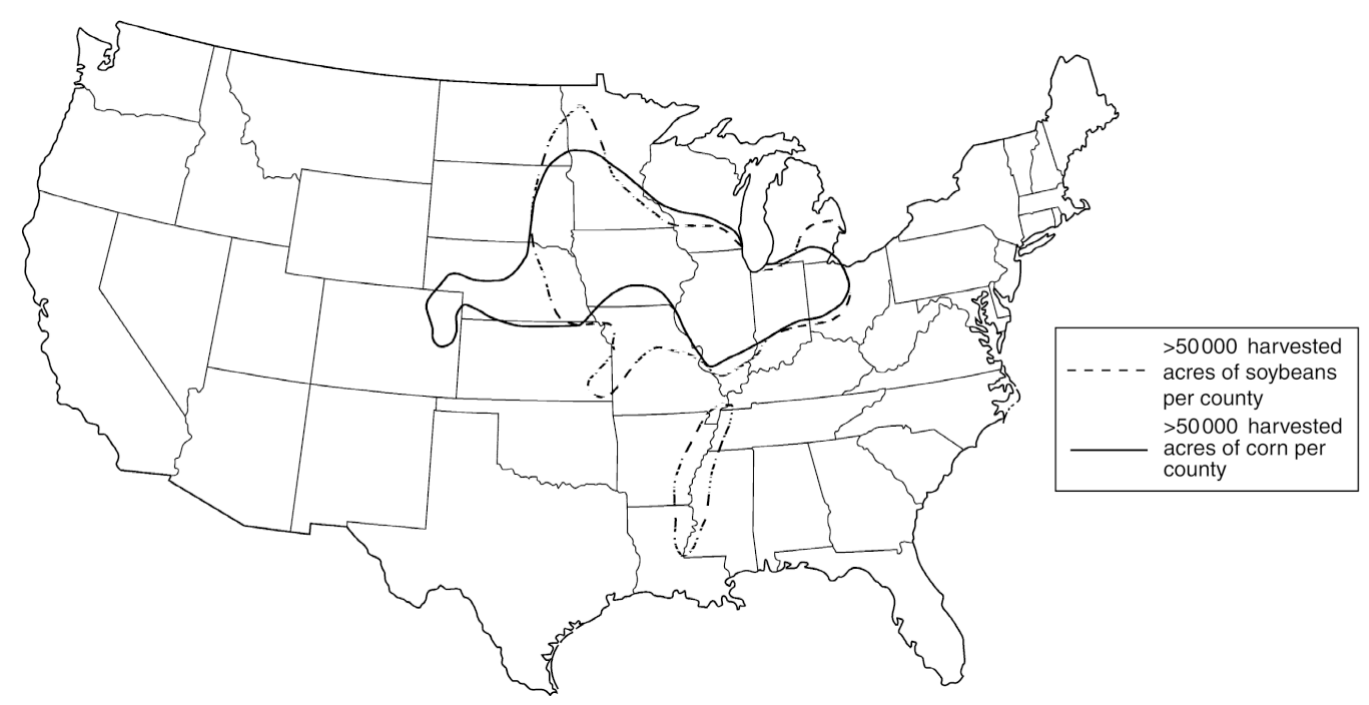

Fig. 3. Principal corn and soybean producing areas in the United States. Outlined areas have more than 50000 acres of harvested crop per county (National Agricultural Statistics Service 2002)

\section{POSSIBLE CAUSES OF TEMPORAL CHANGES IN DEW-POINT VALUES}

Prior research speculated that high dew-point values in recent Chicago heat events were not solely the result of advection; regional enhancement of moisture played a major role (Kunkel et al. 1996, Palecki et al. 2001). Chicago is located in one of the world's greatest corn and soybean growing areas, which stretches from Nebraska through Indiana (Fig. 3). Given adequate soil moisture, healthy and growing corn and soybean plants are efficient at moving water from the ground to the lower atmosphere (Bernstein 1955). Two factors related to corn and soybean growth indicate that transpiration is a major regional source of water vapor at the time of Chicago's short-duration heat events. First, the ratio of evapotranspiration to open pan evaporation measurements (Fig. 4) is highest (ratios greater than 0.7 ) on average between July 10 and September 1 (AlKaisi 2000). The most active growth for Midwest corn and soybean crops (and thus the greatest use of water by the plants) occurs during this period, with the maximum water use generally occurring earlier for corn than soybeans. Only 2 of the 13 short-duration events occurred outside this period in late June or early July. Second, evaporation rates are highest at the beginning 


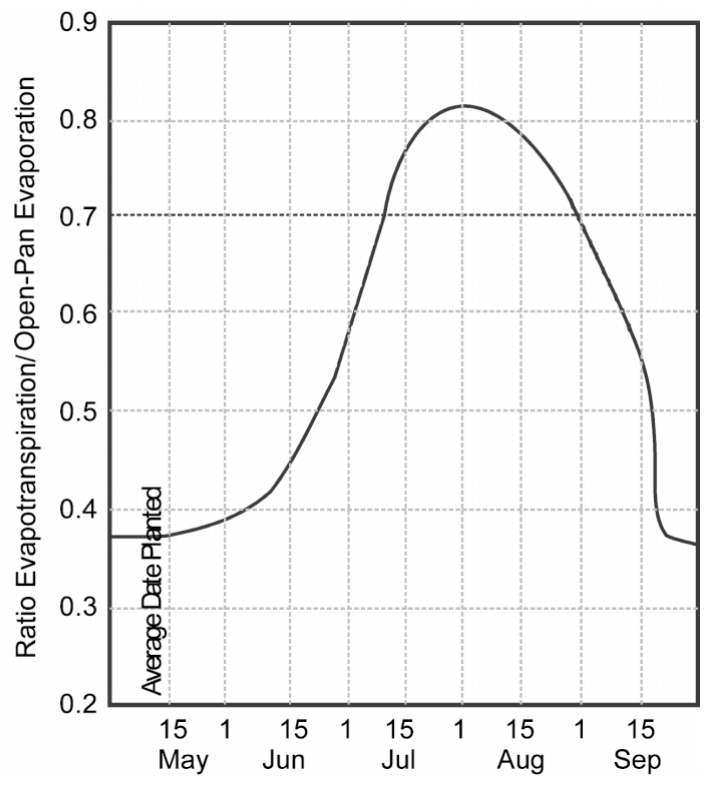

Fig. 4. Ratio of evapotranspiration to open-pan evaporation measurements in the Midwest (Al-Kaisi 2000)

of the crop growing season (before emergence), then decrease through the summer, while transpiration rates are just the reverse, beginning with relatively low values in early May and then increasing through the summer (Al-Kaisi 2000). As corn and soybean plants grow and mature, the leafy canopy closes (generally in early July), and the rate of transpiration begins to exceed evaporation (Al-Kaisi 2000).

Given the results described in the previous section, a goal of the study was to determine how changes in agricultural practices over the $75 \mathrm{yr}$ period influenced the amount of evapotranspiration, more specifically transpiration, in this region. If changing agricultural practices suggest increasing transpiration and thus higher dew points, why was there not a direct relationship between dew-point levels and the occurrence of the 13 events through time (i.e. a steady increase in short-duration heat event dew-point levels over time)? These issues could be more easily addressed if longterm direct evapotranspiration measurements from corn and soybean fields existed. Without direct evidence, indirect factors which could influence summer evapotranspiration from year-to-year were considered: 2 factors, adequate moisture conditions prior to the event and long-term changes in agricultural practices, were examined.

\subsection{Antecedent moisture conditions}

Kunkel et al. (1996) and Palecki et al. (2001) noted that wet conditions in large parts of the Midwest existed prior to the July 1995 and July 1999 short-duration heat waves and concluded that these may have helped to enhance dew-point levels in Chicago through enhanced crop evapotranspiration. The relative importance of soil moisture to the development of Midwestern crops and to the related evapotranspiration was addressed for all 13 events. At issue was determining whether wetter conditions existed prior to high-dew-point Chicago heat waves.

Because soil moisture data sets do not exist across all areas of the Midwest and most soil moisture networks have only been in use for short periods of time (a decade or two), these data sets are limited for use in historical assessments of antecedent soil conditions. Hence, a proxy data set, climate division precipitation data (NCDC TD9640), was chosen to provide an indication of available water for use by corn and soybean crops.

For each event, precipitation anomalies were determined from May 1 to the day up to and including the first day of the event (e.g. event starting July 16) for climate divisions using consecutive non-overlapping 10 or $11 \mathrm{~d}$ periods (e.g. May 1-10, May 11-20, May 21-31, June 1-10, June 11-20, June 21-30, and July $1-10$ ) and the number of days fewer than 10 prior to the event (e.g. July 11-16). May 1 was selected because it represents the average start of the growing season in northern Illinois (US Department of Commerce 1968). Multi-day periods were used rather than monthly totals because precipitation events could occur in only one part of the month and be obscured by a monthly total. Crops are more sensitive to water availability at various stages of growth such as emergence, pollination, tasseling, and filling the ear or pods (Shaw \& Newman 1991), so analysis of precipitation over a $10 \mathrm{~d}$ period versus a whole month would detect when the rain fell in relation to the growth stage of the plant during that time. Atmospheric water vapor is transported through surface advection into the Chicago region. Thus, precipitation anomalies in regions that could influence the city during these short-duration heat waves had to be considered. Daily averaged wind data from the Midway station during these events indicated that the average daily wind speed was $3.9 \mathrm{~m} \mathrm{~s}^{-1}(8.7 \mathrm{mph})$, with a standard deviation of $0.7 \mathrm{~m} \mathrm{~s}^{-1}(1.6 \mathrm{mph})$, and the average daily wind direction was $228^{\circ}$, with a standard deviation of $25^{\circ}$. To provide a regional perspective on moisture anomalies, data were obtained for 5 Illinois climate divisions located to the west, southwest, and south of Chicago (Fig. 5). Climate division data were chosen due to the variable 'hit or miss' convective nature of summer precipitation.

The precipitation departures from average for each climate division were developed for each heat event. These climate division anomalies were then averaged 


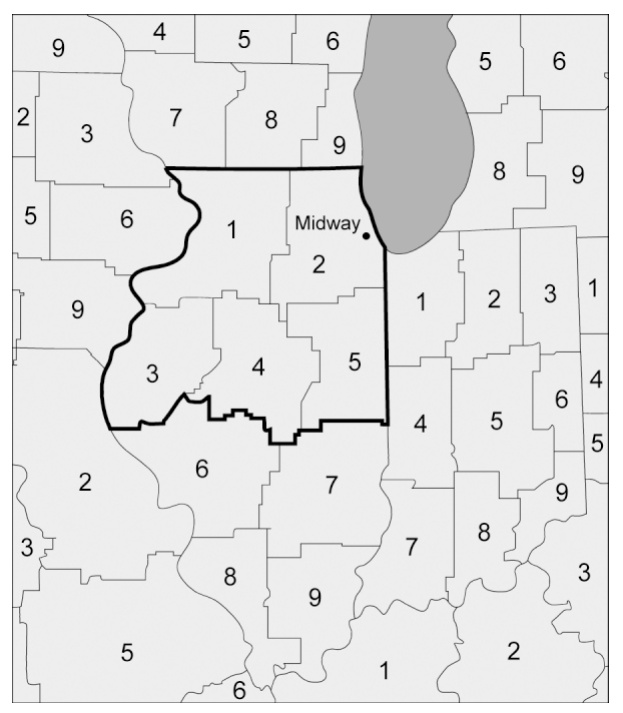

Fig. 5. Midwestern climate division zones. This study examines precipitation and agricultural data for Illinois zones 1-5 (i.e. northern Illinois)

to provide a regional precipitation anomaly for northern Illinois. Two precipitation periods appeared to be related to dew-point levels experienced during the 13 heat waves. May total precipitation was generally average to above average (monthly anomaly $\geq-25 \mathrm{~mm}$ [-1.00 inch]) prior to a high-dew-point heat wave (Fig. 6). The three 10/11 d periods in May were combined because the corn and soybean growth stages that occur in May-planting, plant emergence, and early leaf development-require small amounts of moisture and thus excessive precipitation goes toward soil moisture recharge for future use (Al-Kaisi 2000). Of the 4 events that occurred following a May with below-average precipitation (monthly anomaly $<-25$ $\mathrm{mm})$, only the 1988 event experienced an average daily dew point $>20^{\circ} \mathrm{C}$. The relationship (R-value)

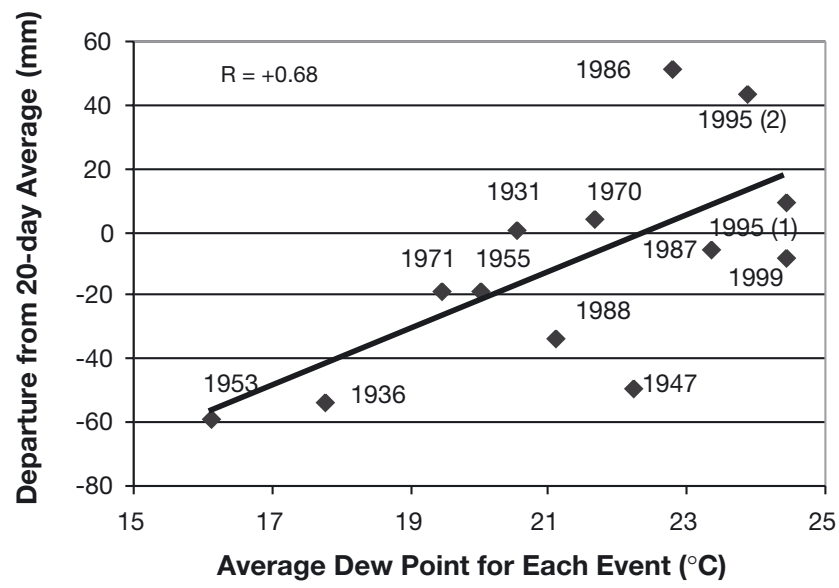

Fig. 7. Regional (northern Illinois) precipitation anomalies for the period $20 \mathrm{~d}$ prior to each heat event plotted against average short-duration heat event dew point value

between average dew point (for each event) and the May precipitation anomaly was +0.60 , indicating a moderate positive relationship. May precipitation surpluses may be related to the occurrence of high dewpoint values because most of the surplus goes into soil moisture recharge or runoff rather than evapotranspiration during this period of the growing season (US Department of Commerce 1968).

When $10 \mathrm{~d}$ periods prior to each event were examined, it appeared that most ( 5 of 6 ) events with higher dew points $\left(\geq 22^{\circ} \mathrm{C}\right)$ experienced average to above-average precipitation (anomaly $\geq-13 \mathrm{~mm}$ [ $-0.50 \mathrm{inch}]$ ) in the period $20 \mathrm{~d}$ prior to the event (Fig. 7). Further examination showed that the top 5 high-dew-point heat events (1986, 1987, July and August 1995, and 1999) had average to above-average precipitation during the $20 \mathrm{~d}$ period prior to the event. All but 2 low-dew-point $\left(<22^{\circ} \mathrm{C}\right)$ heat events were preceded by below-average (anomaly $<-13 \mathrm{~mm}$ ) precipitation during this $20 \mathrm{~d}$ period prior to the event. The R-value, +0.68 , was greater than that found for the

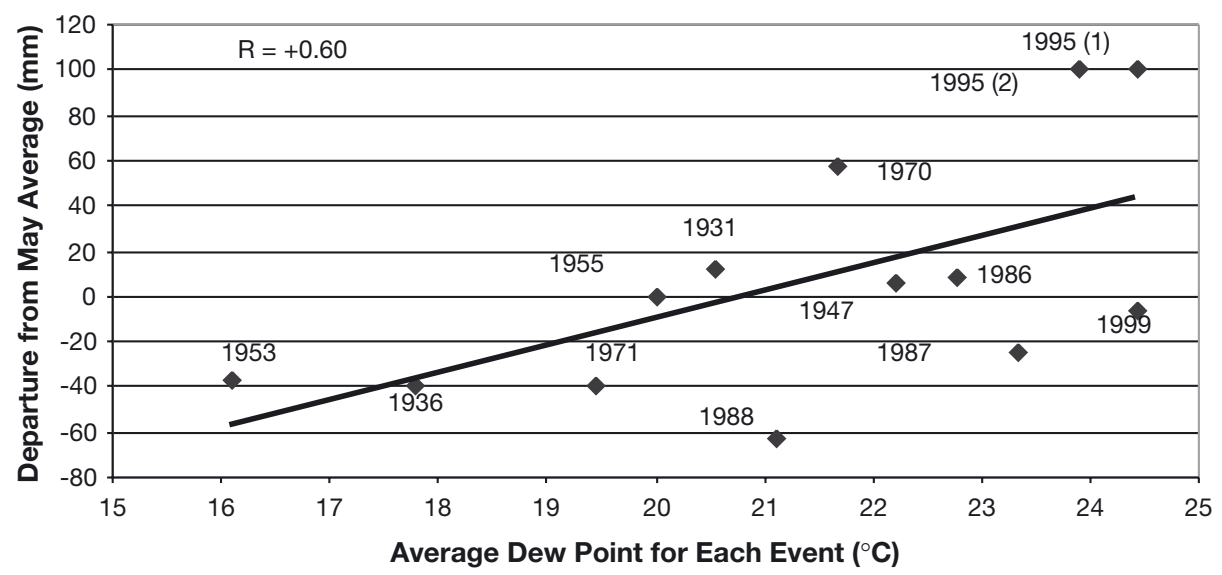

Fig. 6. Regional (northern Illinois) May precipitation anomaly plotted against average short-duration heat event dew-point value 

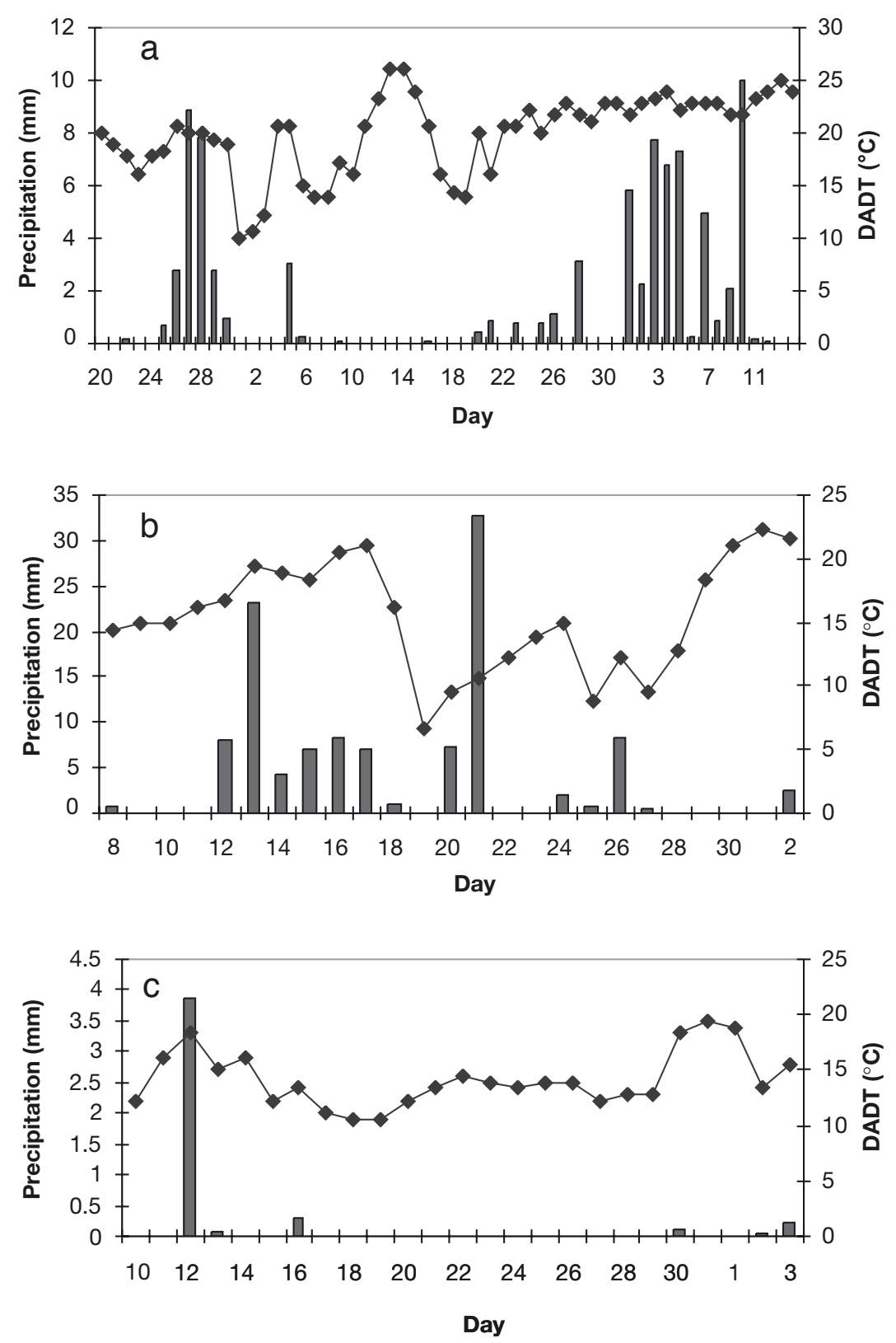

Fig. 8. Daily precipitation amounts and average dew point temperature (DADT) values prior to and including (a) the 1995 events (Jun 20 to Aug 14), (b) the 1970 event (Jun 8 to Jul 2), and (c) the 1953 event (Aug 10 to Sep 3) the distribution). Typically, dew-point levels experience a relative minimum a day or so after a significant precipitation event (total event precipitation $>25 \mathrm{~mm}$ ) has ended (see 1995 and 1970), which may be partially related to an air mass change. However, dewpoint values increase over a number of days to levels generally higher than those prior to the precipitation event, as the synoptic conditions associated with short-duration heat waves develop. In the 1953 event, less than $10 \mathrm{~mm}$ of precipitation occurred in the $20 \mathrm{~d}$ prior to the event, and thus dewpoint values did not show a multi-day increase in the days prior to the event. This lack of precipitation also appears to explain the relatively low dew points experienced during the 1953 event. Regional precipitation anomalies appear to explain dew-point differences among short-duration heat events and may assist those trying to plan for dew-point conditions during future short-duration Chicago heat events.

\subsection{Changes in agricultural practices}

Recent research has indicated that regional land-cover/land-use changes can have a significant impact on regional and global climates (Pielke et al. 2002). Corn and soybean crops have been grown continuously over a large portion of the Midwest during the past $75 \mathrm{yr}$, and to many this represents a non-changing land cover. This land cover has always contributed to surface atmospheric water vapor concentrations through evapotranspiration (Bernstein 1955); however, changes in agricultural practices and corn and soybean production over the past century may have had an impact on the amount of evapotranspiration.

As discussed in the previous section, the average dew-point value that occurs in a given short-duration Chicago heat wave appears to be related to regional precipitation anomalies prior to the event. However, the growing season precipitation anomalies prior to the 1936 and 1988 heat events were similar (both with much-below-average precipitation in May and in the days preceding the event), yet the average dew point 
a
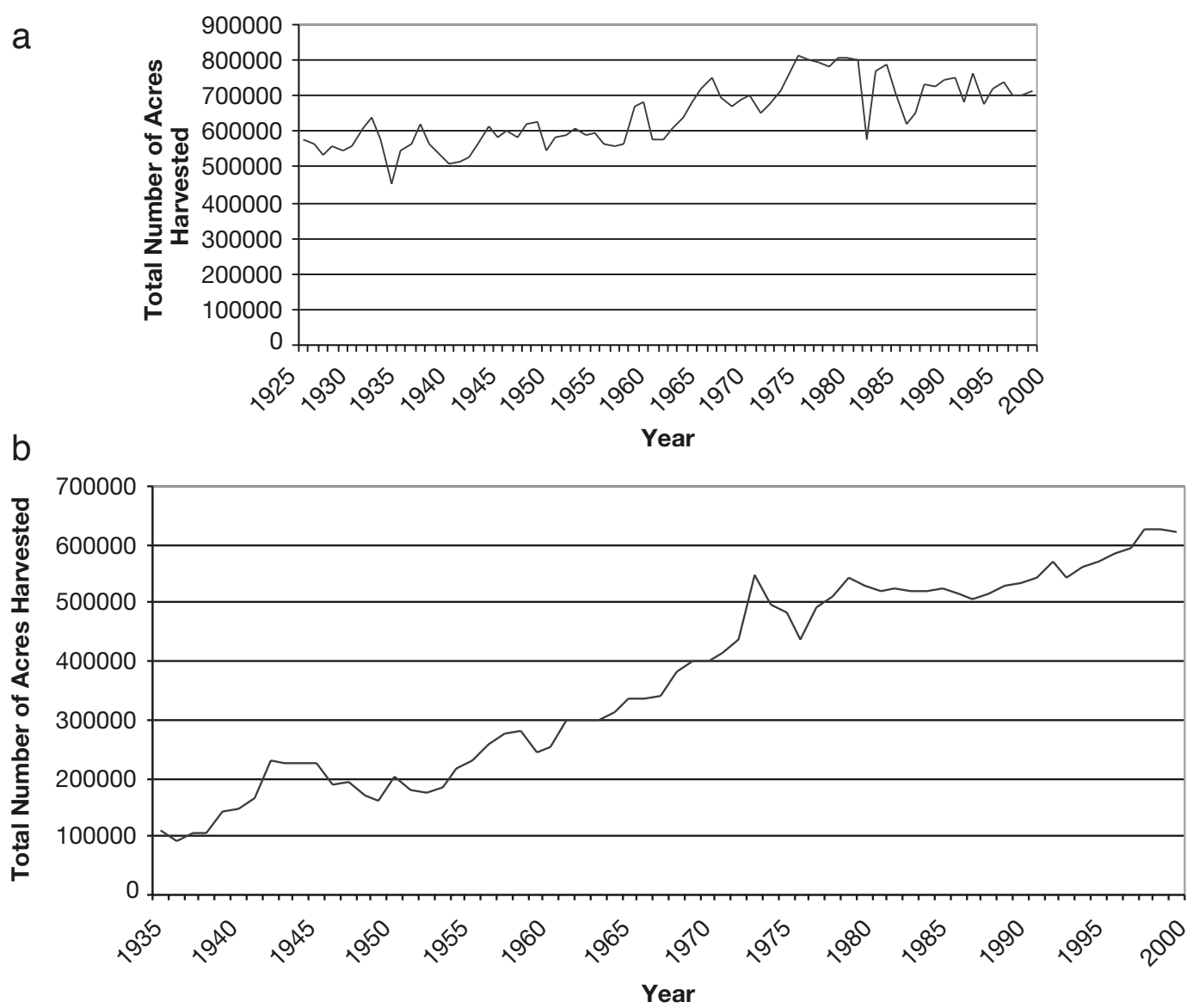

Fig. 9. Annual number of northern Illinois acres harvested in (a) corn (1925-2000) and (b) soybean (1935-2000). Data from Illinois Agricultural Statistics Service (2002)

was nearly $4^{\circ} \mathrm{C}$ higher during the later event. A similar comparison can be made between the heat events in 1999 and 1931 (both experiencing near-average precipitation), and again the average dew-point difference was $4^{\circ} \mathrm{C}$ (1999 event higher). This indicated that despite similar precipitation anomalies, average dew points in more recent heat events have been higher than those that occurred earlier. In an effort to explain these average dew-point differences, historical changes in agricultural practices such as changes in planting densities, weather-sensitive hybrids, cultivation techniques, and acreage planted/harvested, were considered.

The number of acres harvested in corn and soybean within the 5 northern Illinois climate divisions increased about $30 \%$ for corn from 1925 to 2000 and approximately $500 \%$ for soybeans from 1935 to 2000 (Fig. 9). Little change in corn harvested acres was noted over the last $30 \mathrm{yr}$ (Illinois Agricultural Statistics Service 2002), while soybean acreage has increased from approximately 100000 to over 600000 acres since 1935. A number of factors, including transitioning pasture land to row crops and using land once considered too marginal for row crops, has offset the number of acres lost to urban sprawl (Greene \& Stager 2001).

Advances in agricultural equipment, expansion of irrigation, more effective herbicides, and decreases in the price of fertilizer allowed corn row spacing to decrease from $102 \mathrm{~cm}$ (40 inches) in the 1970s (and prior years) to $76 \mathrm{~cm}$ (30 inches) in the 1980 s at a large number of farms (Lauer 1996). Due to this change, the number of corn seeds planted per acre increased from near 18000 to approximately 30000 . The percentage of acres in Illinois where row spacing has narrowed increased from approximately $0 \%$ in 1975 , to $10 \%$ in 1985 , to $20 \%$ in 1995 , to $37 \%$ in 2000 (Paszkiewicz \& Butzen 2001). Multiplying the number of acres in corn times the number of corn seeds planted indicated that the total number of corn plants in northern Illinois fields has increased even faster than corn acreage, up nearly $60 \%$ over the period 1925 to 2000 (Illinois Agricultural Statistics Service 2002) (Fig. 10). Similar changes in plant density over the past 20 yr have occurred with soybeans, suggesting that examining just the number of acres in soybeans would provide an underestimate of total soybean plants in northern Illi- 


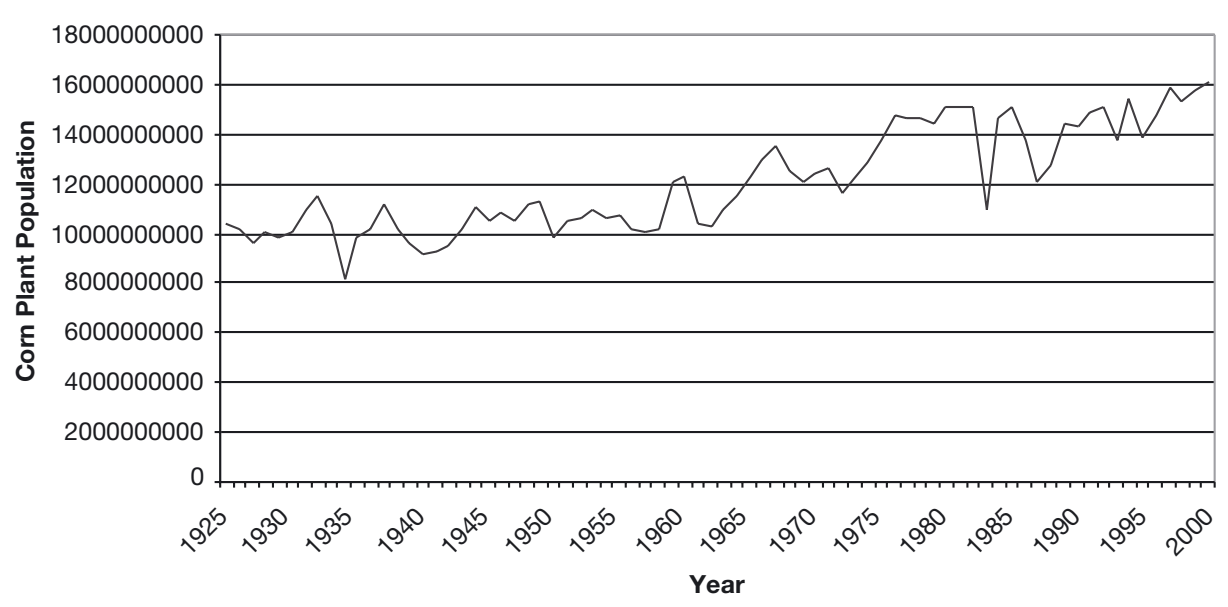

Fig. 10. Annual total number of corn plants in northern Illinois, 1925-2000. Data from Illinois Agricultural Statistics Service (2002)

nois. The impacts of these changes on total regional evapotranspiration amounts are not well understood. However, with more plants in a given acre, there is greater leaf area (Bernstein 1955) from which transpiration can occur (given an adequate moisture supply) and the opportunity for higher surface dew points exists.

An example was developed to estimate the change in transpiration due to crop density change. In a field with $102 \mathrm{~cm}$ row widths, the number of corn plants per square meter is 4.4. During the period between July 15 and August 15 the ratio of evapotranspiration to open pan evaporation is approximately 0.8 (Fig. 4). An approximate pan evaporation value for northern Illinois on a sunny day in this period is $7.5 \mathrm{~mm}$, and thus, the daily evapotranspiration amount is approximately $6 \mathrm{~mm}$, which is similar to values Mahmood \& Hubbard (2002) found in Nebraska. At this time of the growing season, the canopy for corn is closed (filled with vegetation), so the vast majority of evapotranspiration is from transpiration. If one assumes that each plant in a square meter uses an equal share of water, then the 4.4 plants $\mathrm{m}^{-2}$ would equally share the $6 \mathrm{~mm} \mathrm{~d}^{-1}$ and transpire $1.36 \mathrm{~mm} \mathrm{plant}^{-1}$. In a field with $76 \mathrm{~cm}$ row widths, the number of corn plants per square meter is 7.4. Assuming that adequate soil moisture exists for plants in this tighter density to transpire at the same daily rate as those in the $102 \mathrm{~cm}$ row widths, then the 7.4 plants $\mathrm{m}^{-2}$ would transpire about $10 \mathrm{~mm} \mathrm{~d}^{-1}$. Although further field research is required to prove whether these values are indeed accurate, transpiration amounts between 10 and $15 \mathrm{~mm} \mathrm{~d}^{-1}$ have been observed for irrigated corn fields with high planting densities in the High Plains (Howell et al. 1996). In terms of land-cover changes, these appear to be modest, especially when considering the impacts related to changes from rural to urban. Nevertheless, more plants grown over the years suggest more water vapor has been given off to the atmosphere.

Besides the planting densities, the hybrid plants used today have been developed to withstand various weather stresses (high heat, excessive rainfall, drought, etc.) and differences in soil types so as to survive in marginal land areas. With the advent of precision agriculture, these seeds are placed in the ground at distances that provide for equal competition for plant growth (Paszkiewicz \& Butzen 2001) and more effective use of moisture.

During the last 20 yr cultivation practices have shifted. Many farmers in Illinois now practice no-till cultivation, leaving the post-harvest materials on the surface, which acts to reduce runoff. The water that previously went into runoff now has a greater chance of going into soil recharge and being available for the following growing season (Ross et al. 1991). Recent increases (last 50 yr) in Midwestern precipitation (Karl \& Knight 1998) were considerably greater than increases in streamflows (Lettenmaier et al. 1994, Lins \& Slack 1999). These results provide indirect evidence of increased sub-surface storage, which could allow enhanced growing-season evapotranspiration. Thus, regional increases in precipitation combined with changes in agricultural practices may have led to higher water vapor levels which may be related to observed increases in cloud cover (Elliott \& Angell 1997).

\section{CONCLUSIONS}

Short-duration extreme heat events, especially those having extended high day- and nighttime temperatures, cause significant social and economic losses in Illinois (Changnon et al. 1996, Changnon 2002). This 
research assessed water vapor levels (measured by dew-point temperature) associated with Chicago Midway's 13 most severe short-duration heat events since 1928. Criteria for selecting heat events were based on recent heat waves that caused numerous deaths.

Event average dew-point values ranged from a minimum of $16^{\circ} \mathrm{C}$ in the 1953 event to a maximum of $25^{\circ} \mathrm{C}$ in the July 1995 event. This average dew-point range of $9^{\circ} \mathrm{C}$ was more than twice the range of the average air temperature $\left(4^{\circ} \mathrm{C}\right)$ experienced in these 13 events. Although average dew points varied among the 13 events, the values were highest during the 3 most recent heat events that occurred in the 1990s. These results are similar to those identified in an earlier study, where the number of summer hourly extreme dew-point $\left(>24^{\circ} \mathrm{C}\right)$ occurrences increased at both Rockford (rural site) and Chicago O'Hare (suburban site) NWS first-order stations since 1980 (Sparks et al. 2002). Assessing the average number of hours per day with dew points greater than or equal to 4 threshold values also produced similar results. The only shortduration heat events to experience hours with dew points that equaled or exceeded $24^{\circ} \mathrm{C}$ have occurred since 1986 , while the only heat events to equal or surpass $27^{\circ} \mathrm{C}$ were in the 1990 s.

Factors associated with Midwestern evapotranspiration were investigated in an effort to explain not only the range of average dew-points experienced during heat waves, but also why recent heat waves have experienced higher average dew points. The temporal variability in average dew point values appears to be related to 2 issues that have impacted regional evapotranspiration: (1) the amount of precipitation that occurred during May and in the period of up to $20 \mathrm{~d}$ immediately prior to an event, and (2) altered agricultural practices involving corn and soybean production. In

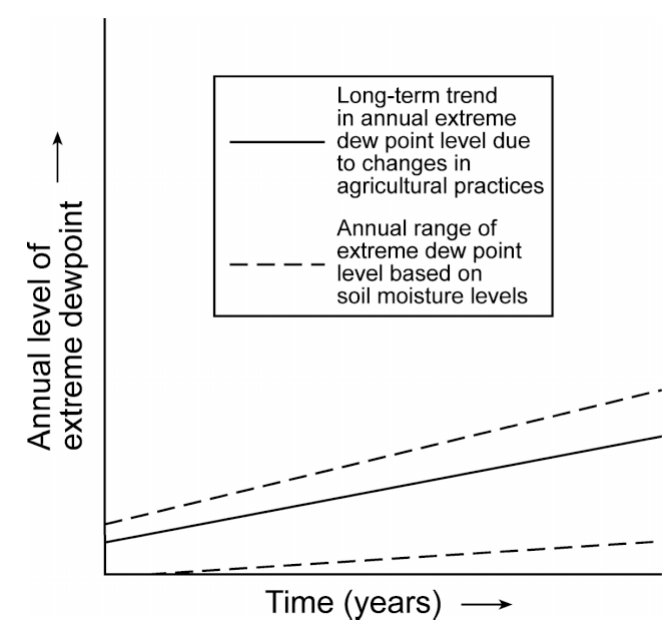

Fig. 11. Conceptual model showing the influence of agricultural changes and growing-season precipitation anomalies on the magnitude of annual extreme dew points the latter, these include use of improved hybrids, more acreage in row crops, cultivation practices, and higher planting densities. The long-term upward trend in dew points appears to be associated with changes in agricultural practices, while the year-to-year differences in the magnitude of extreme dew point values is related to growing season precipitation anomalies (Fig. 11).

A combination of factors must act together to develop extremely high dew points during an extreme heat event. Regional factors, such as adequate moisture conditions and a more evapotranspirative land cover, rather than large-scale advective processes, are likely playing a more active role in developing high surface water vapor concentrations during recent heat events. These results provide further indication that even small and over-looked changes in land-cover qualities may have an important influence on regional climate variability and change.

Acknowledgements. The authors wish to thank those who participated in earlier dew point projects including Soren Hall, Ryan Lauritsen, Eric Musselman, Jesse Sparks, Jason Starke, and Kady Wrona, for their insights. We would like to thank the anonymous reviewers, Mace Bentley, Stan Changnon, Harry Leffler, Gilbert Sebenste, and Elwynn Taylor for their comments and suggestions. Finally we would like to thank Lenny Walther and Jodi Harlan of Northern Illinois University's cartography lab for creating a number of the figures in the paper.

\section{LITERATURE CITED}

Al-Kaisi M (2000) Crop water use or evapotranspiration. Department of Agronomy, Cooperative Extension Service, Iowa State University. Ames. Available at http://www. ent.iastate.edu/ipm/icm/2000/5-29-2000/wateruse.html

Bentley ML, Mote TL (1998) A climatology of derechoproducing mesoscale convective systems in the central and eastern United States. Part I: Temporal and spatial distribution. Bull Am Meteorol Soc 79:2527-2540

Bernstein L (1955) The needs and uses of water by plants. In: Water: the yearbook of agriculture 1955. The United States Department of Agriculture, Washington, DC, p 18-25

Chang JT, Wetzel PJ (1991) Effects of spatial variations of soil moisture and vegetation on the evolution of a prestorm environment: a numerical case study. Mon Weather Rev 119:1368-1390

Changnon D (1993) Variability in high temperature extremes in the southeastern United States. Phys Geogr 14:599-611

Changnon SA (2002) Increasing losses from weather extremes in Illinois: their causes and future implications. Trans Illinois St Acad Sci 95:47-57

Changnon SA, Kunkel KE (1999) Record flood-producing rainstorms of 17-18 July 1996 in the Chicago metropolitan area. Part I: Synoptic and mesoscale features. J Appl Meteorol 38:257-265

Changnon SA, Kunkel KE, Reinke BC (1996) Impacts and responses to the 1995 heat wave: a call to action. Bull Am Meteorol Soc 77:1497-1506

Cohen BM, Kosar DR (2000) Humidity issues in bin energy 
analysis: what engineers can do to achieve a compact but representative data set. Heat/Piping/Air Cond Eng 72: 65-78

Elliott WP (1995) On detecting long-term changes in atmospheric moisture. Clim Change 31:349-367

Elliott WP, Angell JK (1997) Variations of cloudiness, precipitable water, and relative humidity over the United States: 1973-1993. Geophys Res Lett 24:41-44

Gaffen DJ, Ross RJ (1999) Climatology and trends of U.S. surface humidity and temperature. J Clim 12:811-828

Greene RP, Stager J (2001) Rangeland to cropland conversions as replacement land for prime farmland lost to urban development. Soc Sci J 38:543-555

Howell TA, Evett SR, Tolk JA, Schneider AD, Steiner JL (1996) Evapotranspiration of corn - Southern High Plains. In: Camp CR, Sadler EJ, Yoder RE (eds) Evapotranspiration and irrigation scheduling. American Society of Agricultural Engineers, San Antonio, TX, p 158-166

Illinois Agricultural Statistics Service (2002) Illinois Agricultural Statistics Service. USDA, Washington, DC. Available at http://www.agstats.state.il.us

Kalkstein LS, Davis RE (1989) Weather and human mortality: an evaluation of demographic and interregional responses in the United States. Ann Assoc Am Geogr 79:44-64

Karl TR, Knight RW (1998) Secular trends of precipitation amount, frequency, and intensity in the United States. Bull Am Meteorol Soc 79:231-242

Kunkel KE, Changnon SA, Reinke BC, Arritt RW (1996) The July 1995 heat wave in the Midwest: A climatic perspective and critical weather factors. Bull Am Meteorol Soc 77 : 1507-1518

Kunkel KE and 11 others (1998) An expanded digital daily database for climatic resources applications in the Midwestern United States. Bull Am Meteorol Soc 79: 1357-1366

Lauer J (1996) Planting corn in rows narrower than 30-Inches. Field Crops 28:423-428

Lettenmaier DP, Wood EF, Wallis JR (1994) Hydro-climatological trends in the continental United States, 1948-88. J Clim 7:586-607

Lins HF, Slack JR (1999) Streamflow trends in the United States. Geophys Res Lett 26:227-230

Mahmood R, Hubbard KG (2002) Anthropogenic land-use

Editorial responsibility: Andrew Comrie,

Tucson, Arizona, USA change in the North American tall grass-short grass transition and modification of near-surface hydrologic cycle. Clim Res 21:83-90

National Agricultural Statistics Service (2002) National Agricultural Statistics Service. USDA, Washington, DC

Palecki MA, Changnon SA, Kunkel KE (2001) The nature and impacts of the July 1999 heat wave in the Midwestern United States: learning from the lessons of 1995. Bull Am Meteorol Soc 82:1353-1367

Paszkiewicz S, Butzen S (2001) Corn hybrid response to plant population. Pioneer Hi-Bred International, Des Moines, Crop Insights 11(6):1-9

Pielke RA Sr, Marland G, Betts RA, Chase TN, Eastman J, Niles JO, Niyogi DS, Running SW (2002) The influence of land-use change and landscape dynamics on the climate system: relevance to climate-change policy beyond the radiative effect of greenhouse gases. Philos Trans R Soc Lond A 360:1705-1719

Riebsame WE, Changnon SA, Karl TR (1991) Drought and natural resources management in the United States: impacts and implications of the 1987-1989 drought. Westview, Boulder, CO

Robinson PJ (2000a) On the definition of a heat wave. J Appl Meteorol 40:762-775

Robinson PJ (2000b) Temporal trends in United States dew point temperatures. Int J Clim 20:985-1002

Ross BB, Dillaha TA, Mostaghimi S, Heatwole CD (1991) Using rainfall simulators for water quality education. J Extension 29(1):1-2. Available at http://www.joe.org/ joe/1991spring/iw3.html

Schafer K, Stark J (1997) Central Iowa dew point comparisonDEWPEX. Central Region Applied Research Papers, 18-05, National Weather Service, Washington, DC

Shaw RH, Newman JE (1991) Weather stress in the corn crop. National corn handbook, Report No. NCH-18: Climate and weather. Purdue University, West Lafayette, IN

Sparks J, Changnon D, Starke J (2002) Changes in the frequency of extreme warm season surface dewpoints in Northeastern Illinois: implications for cooling system design and operation. J Appl Meteorol 41:890-898

US Department of Commerce (1968) Climatic atlas of the United States. Environmental Data Service, Washington, $\mathrm{DC}$

Submitted: May 10, 2002; Accepted: May 30, 2003

Proofs received from author(s): August 21, 2003 